\title{
Fen Bilgisi Öğretmen Adaylarının Hücre Organelleri Konusundaki Kavramsal Anlama Düzeyleri
}

\author{
Yeşim Koça*, Evrim Sönmez \\ a, b Sinop Üniversitesi, Eğitim Fakültesi, Sinop.
}

$\ddot{O} z$

Bu çalışmanın amacl; Genel Biyoloji I Dersini almış Fen Bilgisi Öğretmen Adaylarının, hücre organelleri konusundaki kavram yanılgılarm ortaya çıkarmak ve bilgi düzeylerini ölçmektir. Bu şekilde hücre ve organelleri konusundaki hangi kavramlarm daha çok akılda kaldığ hangi bilgilerin unutulduğu tespit edilerek bir takım sonuçlar ve öneriler ortaya çıkarılacaktır. Öğrencilerde var olan kavram yanılgllarının hangi konularda yoğunlaştığının belirlenmesi ve hangi konuları ve kavramları öğrenmekte daha çok güçlük çektiklerinin ortaya konması, buna bağh olarak bir öğrenim ortamı ve metodu geliştirmek fen bilimleri eğitiminde çok önemlidir. Çalışma, Sinop Üniversitesi Eğitim Fakültesi Fen Bilgisi Öğretmenliği 3. Simff'ta öğrenim gören 45 öğretmen adayla gerçekleştirilmiştir. Bu araştırmada nitel araştırma yöntemi kullanılmıştır. Öğrencilere hücre organelleri konusunda 13 açık uçlu sorudan oluşan form uygulanmıştır. Elde edilen veriler içerik analiz yöntemiyle analiz edilmiştir. Araştırmaya dahil edilen öğrencilerin lisans öğrenimlerinin 2. sınıfindaki Genel Biyoloji I dersini almış olmalarına rağmen, özellikle organeller konusundaki bazı önemli kavramlar hatırlayamadıkları veya hatalı ve eksik bilgiye sahip olduklar görülmüştür. Elde edilen bulgular göz önüne alınarak var olan eksik veya yanlış bilgilerin düzeltilmesi ve kahıı bilgiye ulaşması için çeşitli öneriler verilmiştir.

Anahtar Kelimeler: Hücre Organelleri, Fen Bilgisi Öğretmen Adayları, Kavramsal Anlama Düzeyi

\section{Conceptual Comprehension Levels of Prospective Science Teachers on the Subject of Cell Organelles}

\begin{abstract}
The purpose of this study is to find out the misconceptions of prospective teachers who took the General Biology I course and to measure their level of information on the subject of cell organelles. Results and suggestions will be presented about which concepts are remembered easily and which information is forgotten. Finding out on which subjects students' misconceptions intensify, which subjects and concepts students have difficulties in learning and developing a learning environment and method based on these is very important in science teaching. The study was conducted with 45 prospective teachers in their third year at Sinop University, Faculty of Education, department of Science Teaching. Qualitative research method was used in the study. The students were given a form including 13 open ended questions on the subject of cell organelles. The data obtained were analyzed through content analysis method. It was found that although the students included in the study took General Biology I course in the second year of their undergraduate education, they could not remember some important concepts about especially the subject of organelles or they had erroneous or incomplete information. Considering the data obtained, various suggestions were given to correct the existing incomplete or wrong information and to reach permanent information.
\end{abstract}

Keywords: Cell organelles, Prospective Science Teachers, Conceptual Comprehension Level. 


\section{GİRIŞ̧}

Kavram yanılgısı, bilimsel olarak doğru kabul edilmeyen ancak öğrencilerin kendilerine özel olarak bir anlam yükledikleri kavramlar olarak tanımlanabilir (Yıldırım ve ark., 2004). Kavram yanılgıları geleneksel öğretim metotlarıyla değişime karşı direnç gösterme özelliği taşır (Aşçı ve ark., 2001; Karataş ve ark., 2003; Cerit ve Sarıkoç, 2005). Öğrenciler öğrenme ortamına gelmeden önce çevrelerindeki farklı olayları kendilerinde olan ön bilgiyi kullanarak yorumlarlar ve buna göre kavrama bir anlam yüklerler.

Fen bilimleri fazlaca soyut kavram içerir. Bu nedenle öğrencilerin bazı bilgileri zihinlerinde oluşturdukları ve yeni bilgiyi kendilerinde önceden var olan bilgilerden yola çıkarak yorumlama eğilimi gösterdikleri bir çok araştırmacı tarafından belirtilmektedir (Palmer, 1999; Köse ve ark., 2003). Öğrenmeyi etkileyen en önemli faktörlerin başında öğrenenin zaten ne bildiği gelir. Mintzes ve Wandersee'ye göre (1998) başlangıçta öğrenilen temel kavramların iyi algılanıp öğrenilmesi, sonraki kavramlardaki doğruluğu arttırma özelliği taşır (Yıldırım ve ark., 2004). Kavram yanılgıları; öğrenci (ön kavram bilgileri, önceden gerekli olan bilgi eksikliği) öğretmen (öğretim stratejisi, yetersiz konu materyali, ezberci anlatım tekniği), kullanılan dil, ders kitabı (içerik eksikliği, şekil ve örneklerin eksikliği, konular arasındaki bütünlük eksikliği, hatalı bilgi), öğrenme ve öğretme ortamı (klasik yöntemler kullanma, uygulama ve görsellere fazla yer vermeme) gibi değişik nedenlere bağlı olarak meydana gelebilir (Gilbert, 1977; Bahar ve ark., 1999, Aşçı ve ark., 2001). Öğrencilerde var olan kavram yanılgılarının hangi konularda yoğunlaştığının belirlenmesi ve hangi konuları öğrenmekte daha çok güçlük çektiklerinin ortaya konması ve buna göre bir öğrenim ortamı ve metodu geliştirmek fen bilimleri eğitiminde çok önemlidir (Novak, 1993). Özellikle fen bilimleri derslerindeki kavramların soyut nitelik taşıması nedeniyle öğrencilerin bu kavramları zihinlerinde canlandırmaları zorlaşmaktadır. Kavram yanılgılarını ortaya çıkarmak için kavram haritaları, kelime eşleştirme, mülakatlar, testler, klasik soru yöntemi, "Vee diyagramları" gibi çeşitli yöntemler kullanılmaktadır (Köse ve ark., 2003; Karataş ve ark., 2003; Turan ve Boyraz, 2004).

Anatomi (Arnoudin ve Mintzess, 1985), protein, enzim, protein sentezi (Selvi ve Yakışan, 2004; Sinan ve ark, 2006) aminoasit ve translasyon (Fisher, 1985), prokaryot ve ökaryot kavramları (Kalaycı, 2017) genetik konuları (Pashley, 1994), fotosentez (Waheed ve Lucas, 1992; Kinchin, 2000; Tekkaya ve Balc1, 2003), solunum (Aşçı ve ark., 2001; Yürük ve Çakır, 2000), hücre (Dreyfus ve Jungwirth, 1988, Yörek 2007), difüzyon ve osmoz (Odom, 1995), hücre bölünmesi (Atılboz, 2004; Emre ve Bahşi, 2006) gibi çeşitli biyoloji konularında kavram yanılgılarıyla ilgili çalışmalar yapılmıştır. Fen Bilimlerinde "canlı" ve "canlılı" gibi kavramları öğrencilerin net bir şekilde öğrenebilmesi için biyolojinin en temel konularından biri olan hücre ve organeller konusunun doğru bir şekilde zihinde canlandırılması gerekmektedir. Eğitim alanında hücre konusuyla ilgili pek çok çalışmaya rastlanmıştır (Dreyfus ve Jungwirth, 1988; Storey, 1991; Gençer, 2006; Jones ve ark., 2006; Minogue ve ark., 2006; Emre ve Bahşi, 2006; Clément, 2007; Yörek, 2007; Maras ve Akman, 2009; Yörek, Şahin ve Uğulu, 2009; Cavas ve Kesercioğlu, 2010; Tasdelen ve Güven, 2012; Topsakal ve Oversby, 2012; 
Taştan Kırık ve Kaya, 2014; Ormancı ve Balım 2016; Yüce ve ark., 2016; Kalaycı, 2017). Fakat hücreyi organelleriyle bir bütün olarak düşünerek organeller konusunda daha fazla çalışma yapmak ve bu konudaki eksiklikleri gidermek oldukça yerinde olacaktır. Hücrenin temel öğelerinin öğrenciler tarafından iyi kavranması ve özellikle de solunum, protein sentezi, fotosentez gibi birçok başka biyolojinin temeli olan konularda da rastladığımız organelleri iyi bilmek, biyolojiyle ilgili temel konuların daha iyi anlaşılmasına yardımcı olacaktır. Anlaşılması zor olan konularda biyoloji derslerinde farklı öğretim yöntemleri kullanılırsa öğrencilerin ezberden uzaklaşıp, biyoloji konularına karşı pozitif tutum sergilemeleri kolaylaşabilir. Hücre konusuna dair öğrencilerin kavramsal bilgi düzeylerinin belirlenmesine dair yapılan çalışmaların ortaokul ve lise düzeyinde yoğunlaştığı görülmektedir. Öğretmen adayları üzerine yapılan çalışmalardan en dikkat çekici olan fen bilgisi öğretmen adaylarının hücre hakkındaki fikirleri çizme yöntemi ile belirlenmeye çalışıldığ1 çalışma olmuştur (Ormancı ve Balım, 2016). Sonuçta, fen bilgisi öğretmen adaylarının hücrenin temel kısımlarını bilseler bile, organellerin yerleri, şekilleri ve bağlantıları hakkında yanlış ve eksik bilgilere sahip oldukları görülmüştür. Bu çalışmanın amac1; Genel Biyoloji I Dersini almış fen bilgisi öğretmen adaylarının, hücre organelleri konusundaki kavram yanılgılarını ortaya çıkarmak ve bilgi düzeylerini ölçmektir. Bu şekilde organeller konusundaki hangi kavramların daha çok akılda kaldığı, hangi bilgilerin unutulduğu tespit edilerek bir takım sonuçlar ve öneriler ortaya çıkacaktır.

\section{YÖNTEM}

\subsection{Araştırma modeli}

$\mathrm{Bu}$ araştırmada nitel araştırma yöntemi kullanılmıştır. Çalışmada, öğrencilere açık uçlu sorulardan oluşan nitel veri toplama aracı kullanılmıştır. Bu amaçla hazırlanan sorular konularında uzman akademisyenler ve ortaöğretim öğretmenleriyle görüşülerek fikirleri alınmıştır. Öğrencilerle görüşme yapılarak, öğrencilere 13 açık uçlu sorudan oluşan form uygulanmıştır. Elde edilen veriler içerik analiz yöntemiyle analiz edilmiştir. Nitel araştırmada amaç, araştırılan konu ile ilgili ayrıntılı ve zengin veriler ortaya koymaktır. Araştırma sonuçlarında güvenirliliği sağlamak için, veriler oldukça ayrıntılı bir şekilde ele alınmalıdır (Creswell, 1994; Yıldırım ve Şimşek, 2006). $\mathrm{Bu}$ bakımdan yaptığımız araştırmada, öğretmen adaylarının sorulara verdikleri yanıtlar oldukça ayrıntılı bir şekilde aktarılmıştır.

\subsection{Araştırma Grubu}

Çalışmanın evreni 2015-2016 Eğitim-Öğretim yılında Sinop Üniversitesi Eğitim Fakültesi Üniversitesi Fen Bilgisi Öğretmenliği programında öğrenim gören öğrencilerden oluşmuştur. Örneklem, bu evrenden seçilen Fen Bilgisi Öğretmenliği 3. Sınıf'ta öğrenim gören 45 öğretmen adayıdır. Öğretmen adayları 2. sinıfta ilk dönem Genel Biyoloji I dersini almaktadırlar. Bu nedenle öğretmen adaylarının hücre organelleri konusundaki bilgilerini ölçmek ve hangi kavramlarda zorluk çekildiğini belirlemek amacıyla, araştırma grubu, bu dersi alan 3. sınıflardan seçilmiştir. Çalışmada, öğrenci ve öğretmenler için açık uçlu sorulardan oluşan nitel veri toplama aracı kullanılmıştır. 


\subsection{Veri Toplama Araçları}

Kavramsal Anlama Testinin hazırlanması için Şubat 1998 tarih ve 2485 sayılı Tebliğler Dergisindeki Orta Öğretim Biyoloji (1-2-3) Taslak Öğretim Programından yararlanılmıştır. Öğrencilere uygulanan formda, Genel Biyoloji I Dersi içeriği de göz önüne alınarak hücre organelleri konusunda en önemli görülen konuları içeren açık uçlu 13 soru yer almaktadır. Bu amaçla hazırlanan sorular konularında uzman akademisyenler ve ortaöğretim öğretmenleriyle görüşülerek fikirleri alınmıştır. Öğrencilere 13 açı uçlu sorudan oluşan form uygulanmıştır.

Kavram analizi yapılarak hazırlanan sorular değişik öğrenci gruplarına uygulanarak sonuçlar değerlendirilmiş ve son haline getirilmiştir. Elde edilen veriler içerik analiz yöntemiyle analiz edilmiştir.

\section{BULGULAR}

Tablo 1. Prokaryotik ve Ökaryotik Hücre Arasındaki Fark

\begin{tabular}{|c|l|c|c|}
\hline \multicolumn{1}{|c|}{ Prokaryotik ve Ökaryotik Hücre Farkı Nedir? } & F & $\%$ \\
\hline 1 & $\begin{array}{l}\text { Prokaryot hücre çekirdeksizdir. Ökaryot hücre çekirdeklidir. } \\
\text { Prokaryot daha basittir, ilkeldir. }\end{array}$ & 6 & 13.3 \\
\hline 2 & $\begin{array}{l}\text { Prokaryotik hücre zarlı organelve çekirdek bulundurmaz. } \\
\text { Ökaryotik hücrede zarlı organel bulunur. }\end{array}$ & 17 & 37.8 \\
\hline 3 & $\begin{array}{l}\text { Prokaryot hücrede çekirdek ve organeller vardır. Ökaryot hücrede } \\
\text { yoktur. }\end{array}$ & 4 & 8.9 \\
\hline 4 & $\begin{array}{l}\text { Prokaryotik hücre gelişmemiş, tek hücreli canlılardır. Çekirdekleri } \\
\text { yoktur. Ökaryotik hücre gelişmiş ve çok çekirdeklidir. }\end{array}$ & 6 & 13.3 \\
\hline 5 & Basit canlılara prokaryot, gelişmiş canlılara ökaryot denir & 8 & 17.8 \\
\hline 6 & Cevap vermeyenler & 4 & 8.9 \\
\hline
\end{tabular}

Bu soruya verilen yanıtlar incelendiğinde 17 öğrenci prokaryot hücrelerde zarla çevrilmiş çekirdek ve organel bulunmadığını, ökaryotlarda ise bulunduğunu söylemiştir. Tersini söyleyen ve kavram yanılgısı veya ters hatırlama yaşayan 4 öğrenci vardır. Bu öğrenciler zarla çevrili organel ve çekirdek kavramlarını hatırlamışlar fakat prokaryot ve ökaryot terimlerini karıştırmışlar ve ters yazmışlardır. Prokaryot hücrenin gelişmemiş tek hücreliler olduğu şeklindeki bir yanlış bilgi cevaplarda gözümüze çarpmaktadır. 6 öğrenci prokaryot en basit canlıdır, 8 öğrenci basit canlılara prokaryot, gelişmiş canlılara ökaryot denir derken, yine 6 öğrenci prokaryot gelişmemiş tek hücreli canlılardır diyerek, önemli bir yanlış bilgiyle karşımıza çıkmaktadırlar. Burada öglana, paramecium gibi tek hücrelilerin ökaryot, bakterilerin ise prokaryot olduğu unutulmuş, hatırlanmamış ve prokaryotlar tek hücrelilik ile bağdaştırılmıştır. 
Tablo 2. DER ve GER arasındaki fark

\begin{tabular}{|c|l|c|c|}
\hline \multicolumn{2}{|c|}{ DER ve GER arasındaki fark nedir? } & F & $\%$ \\
\hline 1 & $\begin{array}{l}\text { DER, düz endoplazmikretikulmdur. Granül yoktur. GER } \\
\text { granüllü endoplazmikretikulmdür. Granül vardır. }\end{array}$ & 30 & 66.7 \\
\hline 2 & Biri granüllü, diğeri düzdür & 5 & 11.1 \\
\hline 3 & $\begin{array}{l}\text { DER, granülü yani ribozomu yoktur. GER granülü yani } \\
\text { ribozomu vardır. }\end{array}$ & 4 & 8.9 \\
\hline 4 & Birinde mitokondri vardır, diğerinde yoktur & 1 & 2.2 \\
\hline 5 & Yapısal ve aktivite farkları vardır. & 2 & 4.4 \\
\hline 6 & Cevap vermeyenler & 3 & 6.7 \\
\hline
\end{tabular}

Bu soruda toplam 34 öğrencinin tam doğru cevabı verdiği görülüyor. 30 tanesi DER düz endoplazmik retikulumdur granülü yoktur derken, 4 öğrenci DER için açılımı yapmamış fakat granülü yani ribozomu yoktur şeklinde bir ayrıntıyı ifade etmiştir. 5 öğrenci granül farkını hatırlamış, fakat hangisinde olduğunu bilememiş, birinde granül var birinde yok şeklinde yanıt vermiştir. 3 öğrenci ise aktivite ve yapısal farkı hatırlamış fakat DER ve GER ayrıntılı tanımını yazamamış, muhtemelen terimleri karıştırmıştır.

Tablo 3. Ribozomların Aktif Hale Gelmesi

\begin{tabular}{|c|l|c|c|}
\hline \multicolumn{2}{|c|}{ Ribozomlar nasıl aktif hale gelir? } & F & \% \\
\hline 1 & Mg aracilığıyla alt ve üst alt birim birleşerek aktif hale gelir & 25 & 55.6 \\
\hline 2 & Özel enzimler aracılığıyla & 6 & 13.3 \\
\hline 3 & Proteinlerin aktifleşmesiyle & 1 & 2.2 \\
\hline 4 & Protein sentezi sırasında & 5 & 11.1 \\
\hline 5 & Karboksil ve R grubu bağlanarak & 2 & 4.4 \\
\hline 6 & Başlangıç kodonuyla & 1 & 2.2 \\
\hline 7 & Cevap vermeyenler & 5 & 11.1 \\
\hline
\end{tabular}

Ribozomların aktif hale gelmesiyle ilgili bu soruda, 25 öğrenci alt ve üst birimin birleşmesiyle olduğunu ve Mg ayrıntısını doğru hatırlamış, geriye kalan öğrencilerin ise özel enzimler yoluyla, karboksil ve $\mathrm{R}$ grubuyla, başlangıç kodonuyla gibi alakasız cevaplar verdikleri görülmüştür. 5 öğrenci ise protein sentezi sırasında olduğunu hatırlamış fakat ayrıntısını ve alt ve üst alt birimleri hatırlayamamıştır.

Tablo 4. Ribozomların Görevi

\begin{tabular}{|c|l|c|c|}
\hline \multicolumn{2}{|c|}{ Ribozomların görevini yazınız } & F & \% \\
\hline 1 & Protein sentezi & 40 & 88.9 \\
\hline 2 & Hücre bölünmesi & 1 & 2.2 \\
\hline 3 & Enerji sağlamak & 2 & 4.4 \\
\hline 4 & Cevap vermeyenler & 2 & 4.4 \\
\hline
\end{tabular}

Ribozomların görevi 40 öğrenci tarafından protein sentezi olarak doğru hatırlanmış, 2 öğrenci mitokondriyle karıştırmıştır. Yine de oldukça yüksek oranda (\%88.9) ribozom görev olarak doğru bilinen bir kavram olarak karşımıza çıkmıştır. 
Tablo 5. Kristanın Bulunduğu Yapı

\begin{tabular}{|c|l|c|c|}
\hline \multicolumn{2}{|c|}{ Krista hangi yapıda bulunur? } & F & \% \\
\hline 1 & Sitoplazmada bulunur & 4 & 8.9 \\
\hline 2 & Mitokondride bulunur & 35 & 77.8 \\
\hline 3 & Ribozomda bulunur & 1 & 2.2 \\
\hline 4 & Çekirdekte bulunur & 2 & 4.4 \\
\hline 5 & Cevap vermeyenler & 3 & 6.7 \\
\hline
\end{tabular}

Kristanın hangi yapıda bulunduğuyla ilgili 5. soruda 35 öğrenci yaklaşık \%77.8'lik bir kısım mitokondri doğru cevabını vermiştir. Sitoplazma, ribozom, çekirdek gibi yanlış cevaplar azınlıktadır.

Tablo 6. Otoliz

\begin{tabular}{|c|l|c|c|}
\hline \multicolumn{1}{|c|}{ Otoliz nedir? } & F & \% \\
\hline 1 & Hücrenin kendi kendini yok etmesi, yemesi, intiharıdır & 15 & 33.3 \\
\hline 2 & Hücrenin su alarak patlamasıdır & 5 & 11.1 \\
\hline 3 & $\begin{array}{l}\text { Hayvan ya da bitki hücresinin kendi enzimleriyle tahrip } \\
\text { olmasıdır }\end{array}$ & 6 & 13.3 \\
\hline 4 & $\begin{array}{l}\text { Hücrenin kendini sindirmesi. Lizozom parçalanır ve hücreyi } \\
\text { sindirir. Intihar gibidir. }\end{array}$ & 12 & 26.7 \\
\hline 5 & Su harcanmasıdır & 3 & 6.7 \\
\hline 6 & Sindirimdir & 1 & 2.2 \\
\hline 7 & Cevap vermeyenler & 3 & 6.7 \\
\hline
\end{tabular}

Otoliz terimi cevaplara baktığımızda öğrenciler tarafından farklı ifadeler kullanılsa da, genel olarak doğru hatırlanmış, 8 öğrenci tarafından su alma ve verme gibi plazmoliz ve deplazmoliz kavramlarıyla bir bağlantı kurulmuş, karıştırılmıştır.

Tablo 7. Kofulun Görevi

\begin{tabular}{|c|l|c|c|}
\hline \multicolumn{2}{|c|}{ Kofulun görevi nedir? } & F & \% \\
\hline 1 & Besin depolama, atık madde depolama, renk maddesi bulundurma & 9 & 20.0 \\
\hline 2 & Atık madde depolama & 5 & 11.1 \\
\hline 3 & Besin ve atık madde depolama & 15 & 33.3 \\
\hline 4 & Hayvanda yoktur, bitkide vardır & 3 & 6.7 \\
\hline 5 & Boşaltım görevi & 3 & 6.7 \\
\hline 6 & Hücredeki fazla suyu atar & 5 & 11.1 \\
\hline 7 & Besin kofulu ve konraktil koful vardır & 5 & 11.1 \\
\hline
\end{tabular}

Kofulun görevinin sorulduğu bu soruda, 3 öğrenci hayvanda yoktur bitkide vardır gibi görev bilgisi taşımayan cevaplar vermişlerdir. Birçok öğrenci tarafından kofulun bir veya iki görevi hatırlanmış, 29 öğrenci besin ve atık madde terimlerini vurgulamıştır. 
Tablo 8. Kromoplastlara iki örnek

\begin{tabular}{|c|l|c|c|}
\hline \multicolumn{2}{|c|}{ Kromoplastlara iki örnek veriniz } & F & \% \\
\hline 1 & Ksantofil, likopin & 10 & 22.2 \\
\hline 2 & Likopin, karoten & 10 & 22.2 \\
\hline 3 & Karoten, likopin, ksantofil & 16 & 35.6 \\
\hline 4 & Lökopen & 2 & 4.4 \\
\hline 5 & Ksantofil, bazofil & 1 & 2.2 \\
\hline 6 & Karoten & 5 & 11.1 \\
\hline 7 & Nötrofil, bazofil & 1 & 2.2 \\
\hline
\end{tabular}

36 öğrenci istenen 2 örneği verebilmiştir. 2 öğrenci kan hücrelerindeki bazofil terimiyle kromoplastları karıştırmıştır. 2 öğrenci de lökopen şeklinde yanlış bir ifade kullanmıştır.

Tablo 9. Kloroplastın Yapısındaki Elemanlar

\begin{tabular}{|c|l|c|c|}
\hline \multicolumn{2}{|c|}{ Kloroplastın yapısındaki elemanları yazınız } & F & \% \\
\hline 1 & E.R., hücre zarı, hücre duvarı, klorofil & 10 & 22.2 \\
\hline 2 & E.R., hücre zarı, klorofil & 5 & 11.1 \\
\hline 3 & Grana, granum, klorofil & 5 & 11.1 \\
\hline 4 & Granül, klorofil & 4 & 8.9 \\
\hline 5 & Stroma, grana, granum, hücre zarı, klorofil & 7 & 15.6 \\
\hline 6 & İç zar, dış zar, grana, granum, stroma, DNA, hücre zarı, klorofil & 4 & 8.9 \\
\hline 7 & DNA, klorofil & 10 & 22.2 \\
\hline
\end{tabular}

Kloroplastın kendine özgü DNA ve RNA içermesi birçok öğrenci tarafından hatırlanmamış, özellikle RNA'yı hiçbir öğrenci yazmamıştır. DNA yazanların oranı \% 31.1'dir. Grana 16 öğrenci tarafından yazılmış, stromayı ise 11 öğrenci yazmıştır. Kloroplastaki çift zar 4 öğrenci tarafından belirtilmiş dış ve iç zar olarak yazılmıştır. E.R. ve hücre duvarı gibi yapıları 15 öğrenci yazarak yanlış bilgi olarak hatırlamışlardır. Kloroplastın yapısını farklı öğrenciler kısmen kısım kısım yazmışlar, bir takım yapıları hatırlamışlar fakat hepsini bir arada tam doğru cevabı veren öğrenci olmamıştır. Sadece özellikle klorofil \% 100 Öğrencinin verdiği bir yanıt olmuş ve kloroplast denildiğinde mutlaka klorofille bağlantı kurulmuştur.

Tablo 10. Çekirdeğin Sıvı Kısmına Verilen Ad

\begin{tabular}{|c|l|c|c|}
\hline \multicolumn{2}{|c|}{ Çekirdeğin sıvı kısmına ne ad verilir? } & F & $\%$ \\
\hline 1 & Nükleoplazma & 18 & 40.0 \\
\hline 2 & Sitozol & 2 & 4.4 \\
\hline 3 & Sitoplazma & 10 & 22.2 \\
\hline 4 & Cevap vermeyenler & 15 & 33.3 \\
\hline
\end{tabular}

Bu soruda en çok dikkat çeken, çekirdek sıvısının bilinmesi gereken en önemli terim olan sitoplazmayla karıştırılmış olması, nükleoplazmanın 18 öğrenci tarafından hatırlanmasına karşın, cevap vermeyenler de göz önüne alındığında 27 öğrencinin (\% 59.9) bu kavramı bilemediği ortaya çıkmıştır. 
Tablo 11. Sentromer

\begin{tabular}{|c|l|c|c|}
\hline \multicolumn{2}{|c|}{ Sentromer nedir? } & F & $\mathbf{\%}$ \\
\hline 1 & Kromozomdaki uzun kol & 5 & 11.1 \\
\hline 2 & Kromozomun kollarına verilen isim & 10 & 22.2 \\
\hline 3 & Kromozom kollarını birleştiren boğum & 10 & 22.2 \\
\hline 4 & Kromozom parçacığı & 7 & 15.6 \\
\hline 5 & Kromozomla ilgili birşey & 5 & 11.1 \\
\hline 6 & DNA parçacığ1 & 2 & 4.4 \\
\hline 7 & Kromozomun kopan parçası & 1 & 2.2 \\
\hline 8 & Cevap vermeyenler & 5 & 11.1 \\
\hline
\end{tabular}

Sentromer kromozom ve genetik konularındaki en önemli terimlerden biri olmasına karşın, tam olarak doğru yanıt verenlerin oranı sadece \%22.2 olmuş, kromozom kollarını birleştiren boğum olarak ifade edilmiştir. Bunun dışında cevap vermeyen 5 öğrenci hariç bütün öğrenciler sentromer ve kromozom arasındaki bağlantıyı doğru hatırlamış krozomomla ilgili bir yapı olduğunu belirtmiştir. Ama doğru cevap sadece 10 kişi tarafından verilmiştir.

Tablo 12. Submetasentrik Kromozom

\begin{tabular}{|c|l|c|c|}
\hline \multicolumn{2}{|c|}{ Submetasentrik kromozom nedir? } & F & $\mathbf{\%}$ \\
\hline 1 & Kromozom çeşididir & 15 & 33.3 \\
\hline 2 & Sentromeri olan kromozomdur & 5 & 11.1 \\
\hline 3 & Kromozomun kolları eşit değildir & 5 & 11.1 \\
\hline 4 & Kromozomun kolları eşittir & 5 & 11.1 \\
\hline 5 & Cevap vermeyenler & 15 & 33.3 \\
\hline
\end{tabular}

Submetasentrik kromozom hatırlanmayan kavram olarak karşımıza çıııor. 5 öğrenci kromozomun kollarının eşit olmadığı kromozom çeşidi olarak doğru cevabı verebilmiş bu aranda sadece \%11.1 olmuştur. Cevap vermeyen öğrenci sayısı 15 öğrenciyle oldukça yüksek bir oranda karşımıza çıkmaktadır.

Tablo 13. Enerji İhtiyacı Fazla Olan Hücrelerde Mitokondri Sayısının Artışı

\begin{tabular}{|c|l|c|c|}
\hline \multicolumn{2}{|c|}{$\begin{array}{c}\text { Enerjiye ihtiyacı fazla olan hücrelerde mitokondri sayısı nasıl } \\
\text { artar? }\end{array}$} & F & $\%$ \\
\hline 1 & $\begin{array}{l}\text { Mitokondri kendine özgü DNA'sı olduğu için kendini } \\
\text { eşleyerek çoğalır }\end{array}$ & 10 & 22.2 \\
\hline 2 & Kendini eşleyerek & 15 & 33.3 \\
\hline 3 & Mitoz bölünme ile & 5 & 11.1 \\
\hline 4 & Mayoz bölünme ile & 2 & 4.4 \\
\hline 5 & ATP harcayarak & 10 & 22.2 \\
\hline 6 & Cevap vermeyenler & 3 & 6.7 \\
\hline
\end{tabular}

$\mathrm{Bu}$ soruda tam doğru cevabı 10 öğrenci (\% 22.2) vermiştir. 15 öğrenci ise DNA'dan bahsetmemiş fakat kendini eşleyerek cevabını vermiştir. 20 öğrenci yaklaşık (\% 44.4) alakasız cevaplar vermiş mitoz ve mayoz bölünme şeklinde yazarak bir kavram karışıklığı yaşamışlardır. 


\section{SONUÇ VE TARTIŞMA}

Bu çalışmada toplam 45 Fen Bilgisi Öğretmenliği 3. sınıf öğrencisine 13 açık uçlu sorudan oluşan form uygulanmış ve nitel araştırma yöntemi kullanılmıştır. Araştırmaya dahil edilen öğrencilerin lisans öğrenimlerinin 2. sınıfındaki Genel Biyoloji I dersini almış olmalarına rağmen, özellikle organeller konusundaki bazı önemli kavramları hatırlayamadıkları veya hatalı ve eksik bilgiye sahip oldukları görülmüştür. Öğrencilerin bu konuları 2. sınıfta işledikleri düşünüldüğünde muhtemelen daha uzun zaman sonra hatırladıkları bilgilerde de azalma beklenebilir. Araştırmada karşılaşılan bazı kavram yanılgılarının da dilden kaynaklandığını göze çarpmaktadır. Özellikle submetasentrik kromozom, likopin, sentromer, sitozol, bazofil, otoliz gibi birçok kavram birbirleriyle veya başka kavramlarla karıştırılmıştır. Örneğin otoliz kelimesi 8 öğrenci tarafından plazmoliz ve deplazmoliz gibi su alma ve su vermeyle ilgili kavramlarla, submetasentrik kromozom ise diğer kromozom çeşitleriyle karıştırılmıştır. Bu çalışmada en çok dikkat çeken yanılgı ve hatalı öğrenme konularından birini prokaryot ve ökaryot gibi biyolojinin iki önemli teriminin hatalı eksik veya yanlış öğrenilmiş olmasıdır. Hücrenin temel öğelerinin öğrenciler tarafından iyi kavranması daha ilerideki konuların doğru öğrenilmesi için oldukça önemlidir (Kete, Horasan ve Namdar, 2012). 1. soruya verilen yanitlar incelendiğinde 17 öğrenci prokaryot hücrelerde zarla çevrilmiş çekirdek ve organel bulunmadığını, ökaryotlarda ise bulunduğunu söylemiştir. Tersini söyleyen ve kavram yanılgısı veya ters hatırlama yaşayan 4 öğrenci vardır. Bu öğrenciler zarla çevrili organel ve çekirdek kavramlarını hatırlamışlar fakat prokaryot ve ökaryot terimlerini karıştırmışlar ve ters yazmışlardır. Prokaryot hücrenin gelişmemiş tek hücreliler olduğu şeklindeki bir yanlış bilgi cevaplarda gözümüze çarpmaktadır. 6 öğrenci prokaryot en basit canlıdır, 8 öğrenci basit canlılara prokaryot, gelişmiş canlılara ökaryot denir derken, yine 6 öğrenci prokaryot gelişmemiş tek hücreli canlılardır diyerek, önemli bir yanlış bilgiyle karşımıza çıkmaktadırlar. Burada öglana, paramecium gibi tek hücrelilerin ökaryot, bakterilerin ise prokaryot olduğu unutulmuş hatırlanmamış ve prokaryotlar tek hücrelilik ile bağdaştırılmıştır. Biyolojinin en temel kavramlarında bile bu tip yanlış ve eksik bilgilerin olması ilköğretimden itibaren farklı öğretim teknojilerine başvurma sıklığının artırılmasını gerektirir. Hücre konusuyla ilgili öğrencilerin bilgi düzeylerinin belirlenmesine yönelik dair yapılan çalışmaların çoğu ortaokul ve lise seviyesindedir. Öğretmen adayları üzerine yapılan çalışma sayısı ülkemizde oldukça azdır. Bu çalışmalardan birinde fen bilgisi öğretmen adaylarının hücre hakkındaki bilgi düzeylerini ölçerken çizme tekniğinden de yararlanılmış (Ormancı ve Balım, 2016), fen bilgisi öğretmen adaylarının hücrenin temel kısımlarını bilseler bile, organellerin yerleri, şekilleri ve bağlantıları hakkında birçok hatalı ve eksik bilgiye sahip oldukları görülmüştür. Kalaycı, 2017 yaptığı çalışmada hem kelime ilişkilendirme hem de çizim tekniğini kullanmış, hücre çizimleri göz önüne alındığında, bu araştırmaya katılan fen bilgisi öğretmen adaylarının hücrenin yapısı ve organelleriyle ilgili yetersizliği görülmüştür. Bu çalışmada ise özellikle organeller konusundaki bilgi ve kavram yanılgılarını ölçmek için oldukça ayrıntılı açık uçlu sorular kullanılmış ve tek tek tüm sorulara verilen cevapların analizi yapılmıştır. Çalışmada dikkat çeken noktalardan 
birisi de organellerle ilgi çok genel bilgilerin daha kolay hatırlandığı, biraz ayrıntıya ve özele inildiğinde kavram yanlışlarının, karıştırmaların ve eksik bilgilerin arttığıdır. Örneğin, ribozomun görevi çoğunluk tarafından protein sentezi olarak yazılırken, ribozom nasıl aktif hale gelir olarak sorulduğunda doğru cevapta hemen bir düşüş göze çarpmaktadır. Yine submetasentrik kromozom nedir denildiğinde adından dolayı kromozomla ilgili bir şey diyenler çoğunluktayken, kolların eşit olamadığı kromozom çeşidi diyenler sadece \%11.1 olmuştur.

Fen bilimleri öğretiminde sık sik geleneksel yöntemlere başvurulması, kavramların doğru hatırlanmasına engel olmaktadır. Farklı yöntemlerin uygulanmaması, kavram yanılgılarının giderilememesine sebep olur. Bu konuda birçok çalışma vardır (Üce ve Sarıçayır, 2002; Akgün ve Aydın, 2009). Kavram yanılgılarını gidermek için zihinde varolan yanlış bilginin değiştirilmesi gerekir (Smith ve ark., 1993). Bu da değişik öğretim teknolojilerinin kullanılmasını beraberinde getirir. Bunlardan biride bilgisayarlardır. Son yıllarda öğretimde bilgisayar teknolojileri önem kazanmıştır (Şahan, 2005, Ünal, 2007). Ses ve animasyonlardan biyolojide daha fazla yararlanmak gereklidir. Böylelikle anlamakta güçlük çekilen konular daha kolay anlaşılacak ve yapılandırılacaktır (Demirci, 2003).

Öğretmen adaylarının fenle ve biyolojiyle ilişkili özellikle hangi konularda ve kavramlarda güçlük çektiklerinin belirlenmesi son derece önemlidir. Kalıcı ve doğru bilginin öğretilebilmesi de ancak uygun ve tekdüze olmayan farklı öğretim teknolojilerinin kombinasyonuyla mümkündür. Fen derslerinde başarısızlık oranının yüksek olmasının en önemli sebeplerinden biride konu içeriklerinin soyut sunulmasıdır (Üstün ve ark., 2001).

Ayrıca üniversite ders kitaplarının öğretmen adaylarının da kavram yanılgısına yol açmayacak şekilde hazırlanması büyük önem taşır (Yağbasan ve Gülçiçek, 2003). Üniversiteyi bitiren öğrencilerin, ortaokul ve lise düzeyinde hücre ve organeller gibi en temel konularda bile eksik hatalı ve yanlış bilgilere sahip olmaları son derece düşündürücüdür. Muhtemelen Genel Biyoloji I dersini almadan önce de lise eğitiminden gelen yanlış kavramlarla dolu olan öğrenci doğruları pekiştirememiş ve kalıcı ve doğru bilgilere ulaşamamıştır.

Aslında eğitimin bir bütün olduğu düşünülürse ilköğretimden itibaren gereken önlemlerin alınması, zaten soyut olan fen bilimlerinde doğru bilgiye ulaşacak birçok metodu ders işlenişinde kullanmak son derece yararlı olacaktır. Lisans eğitiminde de özellikle biyoloji derslerinde laboratuvar uygulamalarını tam ve düzgün yaptırmak öğrencinin bilgiye, yaparak, yaşayarak ulaşmasını sağlayacak ve kavramlar daha kalıcı hale gelecektir. Çepni ve ark. (2006), fotosentez konusunda bilgisayar destekli öğretim materyalinin 11. Sınıf öğrencilerinde etkisini incelemiş, çalışma sonucunda özellikle bu yöntemin bilişsel alanı anlama konusunda oldukça etkili olduğunu ancak fotosentezle ilgili bazı kavram yanılgılarının düzeltilmesinde çok etkili olmadığı bulunmuştur. Dilek (2006), sekizinci sınıf öğrencilerinde fotosentez ve solunum konusunda çoklu zeka modelini uygulamış, sonuç olarak birçok konuyu daha iyi anladıkları tespit edilmiştir. Sert Çıbık ve ark. (2008) fotosentezle ilgili bilgilerde, gösteri deneylerinin 
etkisini fen bilgisi öğretmen adaylarında incelemiş, kavramsal değişim yaklaşımına dayalı fen bilgisi laboratuvarı uygulamaları dersini alan öğrencilerin başarılarının geleneksel yaklaşıma göre fen bilgisi laboratuvarı dersini alan öğrencilerden çok daha yüksek olduğunu tespit etmiştir. Bu çalışmalardan da görüleceği gibi tek bir öğretim yöntemi değil birkaç yöntemin uygulanması ve özellikle deneye dayalı tekniklerin öğrencinin mümkün olduğunca katılımıyla gerçekleştiği yöntemler biyolojide başarıyı arttıracaktır.

Kromozom, sentromer, ribozom,kloroplast gibi önemli organellerin görsel olarak öğrenciye aktarılması, bir takım hücre modelleri ve bilgisayar animasyonları kullanmak son derece önemlidir. Unutulmaması gereken en önemli nokta görsel olarak verilen bilgi çok daha fazla kalıcı hale gelir, ezberlenen kavram çabuk unutulur. Hücre zarından madde geçişiyle ilgili bir konu, düz bir anlatım yerine basit bir deney düzeneğiyle uygulamalı olarak gösterildiğinde çok daha net anlaşılacaktır. Tüm konuları deneyle vermek elbette mümkün değildir bu durumda da özellikle hücre ve organel modelleri kullanmak, animasyonlardan yararlanmak, öğretilen kavramı mümkün olduğunca örneklendirmek her zaman ezbercilikten daha iyi bir sonuç getirecektir. Bu konuda öğretim üyesi ve öğretmenlere çok büyük bir görev düşmektedir. Bunun dışında özellikle öğretmen adaylarının üniversiteye hangi yanlış ve eksik bilgilerle geldiklerini tespit etmek amacıyla dönem başında o ders konularını içeren bir takım testlerle öğrencilerin o zamana kadar ne bildikleri, hangi kavramları daha çok karıştırdıkları test edilebilir. Çünkü her zaman yanlış bilgiyi değiştirmek, o konuda bilgisi olmayan birine bir bilgiyi aktarmaktan daha zordur.

\section{KAYNAKÇA}

Akgün, A. ve Aydın, M. (2009). Erime ve Çözünme Konusundaki Kavram Yanılgılarının ve Bilgi Eksiklerinin Giderilmesinde Yapılandırmacı Öğrenme Yaklaşımına Dayalı Grup Çalışmalarının Kullanılması. Elektronik Sosyal Bilimler Dergisi, 8 (27): 190-201.

Arnoudin, M. and Mintzess, J. J. (1985). Students' Alternative Conceptions Of The Circulatory System: Across Age Study. Science Education. 69: 721-733.

Aş̧̧ı, Z., Özkan, Ş. ve Tekkaya, C. (2001). Students' Misconceptions About Respiration: A CrossAge Study. (Öğrencilerin Solunum Konusundaki Kavram Yanılgıları: Karşılaştırmalı Bir Çalışma). Ĕğitim ve Bilim (Education and Science, 26 (120): 29-36.

Atılboz, N.G. (2004). Lise 1. Sınıf Öğrencilerinin Mitoz ve Mayoz Bölünme Konuları İle İlgili Anlama Düzeyleri ve Kavram Yanılgılar. G.Ü. Gazi Eğitim Fakültesi, 24 (3): 147-157.

Bahar, M., Johnstone, A. H. and Hansell, M. H. (1999). Revisiting Learning Difficulties in Biology. Journal of Biological Education, 33 (2).

Cavas, B. and Kesercioğlu, T. (2010). Qualitative Study On Student' Understanding And Misconceptions Regarding The Living Cell. e-J. New World Sci. Acad., 5(1): 321-331.

Cerit, N. ve Sarıkoç, A. (2005). A Study About Misconceptions Of The Lycee One Students Concerning The Matter And its Features. Selçuk Üniversitesi Ĕ̆itim Fakültesi Dergisi, 19: 123-135. 
Clément, P. (2007). Introducing the Cell Concept with Both Animal and Plant Cells: A Historical and Didactic Approach. Science and Education, 16: 423-440.

Creswell, J. W. (1994). Research Design: Qualitative, Quantitative, and Mixed Methods Approaches. 2nd edn. London: Sage, Thousand Oaks.

Çepni, S., Taş E. and Köse S. (2006). The Effects of Computer Assisted Materials on Students' Cognitive Levels, Misconceptions and Attitude towards Science. Computers and Education, 46 (2): 192-205.

Demirci, N. (2003). Bilgisayarla Etkili Öğretme Stratejileri ve Fizik Öğretimi. Ankara: Nobel Yayıncilik.

Dilek, F. (2006). 8. Sınıf Öğrencilerinin Fotosentez ve Solunum Konularını Kavramalarına ve Fene Karşı Tutumlarına Çoklu Zeka Modelinin Etkisi. Yayınlanmamış Yüksek Lisans Tezi, Gazi Üniversitesi, Eğitim Bilimleri Enstitüsü, Ankara.

Dreyfus, A. and Jungwirth, E. (1988). The Cell Concept of 10th Graders: Curricular Expectations and Reality. International Journal of Science Education, 10: 221- 229.

Emre, İ. ve Bahşi, M. (2006). Fen Bilgisi Öğretmen Adaylarının Hücre Bölünmesiyle İlgili Kavram Yanılgıları. Doğu Anadolu Bölge Araştırmaları (DAUM), 4 (3): 70-73.

Fisher, K. M. (1985). “A Misconception in Biology: Amino Acids and Translation". Journal of Research in Science Teaching, 22 (1): 562.

Gençer, Z. (2006). İlköğretim Öğrencilerinin (6., 7. ve 8. Sınıflar), Hücre Konusundaki Kavram Yanılgılarının Tespiti Üzerine Bir Araştırma. Yayınlanmamış Yüksek Lisans Tezi, Gazi Üniversitesi, Ankara.

Gilbert, J. K. (1977). The Study of Student Misunderstandings in The Physical Sciences. Research in Science Education. 7: 165-171.

Jones, M. G., Minogue, J., Oppewal, T., Cook, M. P. and Broadwell, B. (2006). Visualizing Without Vision at the Microscale: Students with Visual Impairments Explore Cells with Touch. Journal of Science Education and Technology, 15 (5): 345-351.

Kalayc1, S. (2017). Determining Pre-Service Science Teachers' Cognitive Structure on The Concepts Of "Prokaryote" and "Eukaryote". e-Uluslararası Eğitim Araştırmaları Dergisi, 8 (3): 46-64.

Karataş, Ö., Köse, S. ve Coştu, B. (2003). Öğrenci Yanılgılarını ve Anlama Düzeylerini Belirlemede Kullanılan İki Aşamalı Testler. Pamukkale Üniversitesi Eğitim Fakültesi Dergisi 1 (13): 54-69.

Kinchin, I. M. (2000). Concept-Mapping Activities to Help Students Understand Photosynthesis and Teachers Understand Students. School Science Review. 82 (299): 11-14.

Köse, S., Coştu, B. ve Keser, Ö. F. (2003). Fen Konularındaki Kavram Yanılgılarının Belirlenmesi: Tga Yöntemi ve Örnek Etkinlikler. Pamukkale Üniversitesi Ĕ̆itim Fakültesi Dergisi, 1 (13): 43-53.

Maras, M. and Akman, Y. (2009). The Understanding Level and Comprehension Mistakes of Students About Cell Biology. National Education, 37 (181): 146-151. 
Minogue, J., Jones, M. G., Broadwell, B. and Oppewall, T. (2006). The Impact of Haptic Augmentation on Middle School Students' Conceptions of the Animal Cell. Virtual Reality, 10: 293-305.

Mintzes, J. J. and Wandersee, J. H. (1998). Research in Science Teaching and Learning: a Human Constructivist View. In J. J. Mintzes, J. H. Wandersee, \& J. D. Novak (Eds.), Teaching Science For Understanding: a Human Constructivist View (pp. 59-92). San Diego, CA: Academic Press.

Novak, J. D. (1993). How Do We Learn Our Lesson?. The Science Teacher, 60: 50-55.

Odom, A. L. (1995). Secondary and College Student's Misconceptions About Diffusion And Osmosis. American Biology Teacher, 57: 409-415.

Ormancı, Ü. and Balım, G. (2016). The Determination of Science Teacher Candidates' Ideas on Cell Subject Through Drawing Method. The Online Journal of New Horizons in Education, 6 (2): 112-123.

Pashley, M. (1994). A-Level Students: Their Problems with Gene and Allele. Journal of Biological Education, 28 (2): 120-127.

Selvi, M. ve Yakışan, M. (2004). Üniversite Birinci Sınıf Öğrencilerinin Enzimler Konusu İle İlgili Kavram Yanılgıları. Gazi Eğitim Fakültesi Dergisi 24 (2): 173-182.

Sert Çıbık A., Diken, E. H. and Darçın, E. S. (2008). The Effect of Group Works and Demonstrative Experiments Based on Ceonceptional Change Approach: Photosynthesis and Respiration. Asia-Pacific Forum on Science Learning and Teaching, 9 (2): 1-22.

Sinan, O., Yıldırım, O., Kocakülah, M. S. ve Aydın, H. (2006). Fen Bilgisi Öğretmen Adaylarının Proteinler, Enzimler ve Protein Sentezi İle İlgili Kavram Yanılgıları. Gazi Eğitim Fakültesi Dergisi, 26 (1): 1-16.

Smith, E. L., Blakeslee, T. D. and Anderson, C. W. (1993). Teaching Strategies Associated with Conceptual Change Learning in Science. Journal of Research in Science Teaching, 30(2): 111-126.

Storey, R. D. (1991). Textbook Errors and Misconceptions in Biology: Cell Metabolism. The American Biology Teacher, 53 (6): 339-343.

Şahan, H. H. (2005). İnternet Tabanlı Öğretim. Eğitimde Yeni Yönelimler (1. Baskı). Editör: Mehmet Bahar. Ankara: Pegem A Yayıncilık.

Tasdelen, O. and Guven, T. (2012). The Evaluation of Cell Biology (Cytology) Laboratory Lesson According to the Ideas of Students. Journal of Turkish Science Education, 9 (2): 155-167.

Taştan Kırık, Ö. and Kaya H. (2014). A Qualitative Study Concerning the 6th Grade Students' Conceptual Structures About the Cell Concept. International Online Journal of Educational Sciences, 6 (3): 737-760.

Tekkaya, C. ve Balcı, S. (2003). Öğrencilerin Fotosentez ve Bitkilerde Solunum Konularındaki Kavram Yanılgılarının Saptanması. Hacettepe Üniversitesi Ĕ̆itim Fakültesi Dergisi, 24: 101-107.

Tekkaya, C., Çapa, Y. and Yılmaz, Ö. (2000). Biyoloji Öğretmen Adaylarının Genel Biyoloji Konularındaki Kavram Yanılgıları. Hacettepe Üniversitesi Ĕ̆itim Fakültesi Dergisi, 18: 140147. 
Topsakal, U. U. and Oversby, J. (2012). Turkish Student Teachers' Ideas About Diagrams of a Flower and a Plant Cell. Journal of Biological Education, 46 (2): 81-92.

Turan, M. ve Boyraz, Z. (2004). Öğretim Materyali Olarak Kavram Haritaları. F.Ü. Doğu Anadolu Bölgesi Araştırmaları Dergisi, 3 (1): 126-131.

Üce, M. ve Sarıçayır, H. (2002). Üniversite 1. Sınıf Genel Kimya Dersinde Asit-Baz Konusunun Öğretiminde Kavramsal Değişim Metinleri ve Kavram Haritalarının Kullanılması. M.Ü Atatürk Eğitim Fakültesi Ĕ̆itim Bilimleri Dergisi, 16: 163-170.

Ünal, S. (2007). Atom ve Molekülleri Bir Arada Tutan Kuvvetler Konularının Öğretilmesinde Yeni Bir Yaklaşım: BDÖ ve KDM'nin Birlikte Kullanımının Kavramsal Değişime Etkisi, Doktora Tezi, KTÜ Fen Bilimleri Enstitüsü, Trabzon.

Üstün, P., Yıldırgan, N. ve Cegiç, E. (2001). Fen Bilgisi Eğitiminde Model Kullanma İle Öğretimin Başarıya Etkisi, Yeni Bin Yılın Basında Fen Bilimleri Ĕ̆itimi Sempozyumu, İstanbul.

Waheed, T. and Lucas, A. M. (1992). Understanding Interrelated Topics: Photosynthesis at Age 14. Journal of Biological Education, 26 (3): 193-200.

Yağbasan, R. ve Gülçiçek, Ç. (2003). Fen Öğretiminde Kavram Yanılgılarının Karakteristiklerinin Tanımlanması. Pamukkale Üniversitesi Eğitim Fakültesi Dergisi, 1(13): $110-128$.

Yıldırım, A. ve Şimşek, H. (2006). Sosyal Bilimlerde Nitel Araştırma Yöntemleri. Ankara: Seçkin Yayıncilik.

Yıldırım, O., Nakiboğlu, C. ve Sinan, O. (2004). Fen Bilgisi Öğretmen Adaylarının Difüzyon ile İlgili Kavram Yanılgıları. BAÜ Fen Bilimleri Enstitüsü Dergisi. 6 (1): 79-99.

Yörek, N. (2007). Öğrenci Çizimleri Yoluyla 9. ve 11. Sınıf Öğrencilerinin Hücre Konusunda Kavramsal Anlama Düzeylerinin Belirlenmesi. Dokuz Eylül Üniversitesi Buca Eğitim Fakültesi Dergisi, 22: 107-114.

Yüce, Z., Önel, A. ve Bekis, E. S. (2016). Öğrenci Çizimleri Yoluyla Ortaokul Öğrencilerinin Hücre Konusundaki Kavramsal Bilgi Düzeylerinin Belirlenmesi. Mersin Üniversitesi Eğitim Fakültesi Dergisi, 12 (2): 616-625.

Yürük, N. ve Çakır, Ö.S. (2000). Lise Öğrencilerinde Oksijenli ve Oksijensiz Solunum Konusunda Görülen Kavram Yanılgılarının Saptanması. Hacettepe Üniversitesi Eğitim Fakültesi Dergisi, 18: 185-191. 